\author{
https://doi.org/10.52449/1857-4114.2020.35-1.06
}

CZU: 796.5:796.015-053.6

\title{
THE ROLE OF ACTIVE TOURISM FORMS ON THE PHYSICAL TRAINING OF 13-14 YEAR OLD STUDENTS
}

\author{
Grosu Maria ${ }^{1}$ \\ ${ }^{1}$ State University of Physical Education and Sports, Chisinau, Republic of Moldova
}

\begin{abstract}
One of the negative parts of the ever-accelerating development of scientific and technological progress is the release of young people from physical exertion, the decrease of their physical activity in the conditions in which modern technology limits human participation in outdoor movement activity. If in the past centuries the consumption of muscle energy in production was higher then now it has decreased considerably. Therefore, hypodynamics has become the most common disease of the century, ie the weakening of human muscle activity, due to sedentary lifestyle and restriction of physical activity. This situation has become one of the reasons for drawing the general public's attention to active forms of recreation and, in particular, to active forms of tourism.

The main forms of active tourism are the land forms. The safety and the technical-tactical level of development of these forms, to a large extent, are based on the initial training of students of different ages, including 13-14 years, for tourism, in which an important role belongs to competitions in the technique of pedestrian tourism. They contribute to the verification and improvement of students' physical training, to the testing of new types of equipment and to the exchange of experience.
\end{abstract}

Keywords: physical training, forms of tourism, active tourism, students aged 13-14, tourist march, tourism technique.

The actuality of the subject. At present, the forms of active tourism are little known and publicized in the Republic of Moldova, but which from year to year are becoming more and more popular among students because they are able to improve their physical training.

In this sense, active tourism is characterized primarily by excursions, marches and tourist competitions, often with a duration of more than 24 hours, in which a certain area is visited outside the place of residence or the practice of tourist activities with educational, cognitive purpose and development of physical training of participants, etc. [4, 9].

At the same time, active tourism is a combination of phenomena and relationships that occur during the trip, requiring proper physical training of participants, characterized by an active way to travel on a route, with energy costs, made for recreational purposes or sports, defined as active forms of recreation, which in our opinion, are differentiated, depending on the form of activity (sports tourism, active tourism and passive tourism). In this context, active tourism is differentiated from other forms of activity by the active and energetic participation of participants in active tourism activities, without obtaining remarkable sports results, but which determines the development of their physical qualities.

According to the authors Вереснева М.A., Новикова Д.С., Фарбей Г.Г. [5, p. 8], active tourism is a special travel activity, being 
characterized by the movement of people in time and space. However, it should be emphasized that not all travel (eg by train, plane, cruise ship, etc.), but only that associated with the use of physical qualities is characteristic of active tourism. Active tourism is that form of tourism that annually stimulates the development of physical training of millions of participants, including students of different ages.

The aim of the research is to determine the role of active tourism forms on the physical training of 13-14 year old students.

\section{Research objectives:}

1. The study of the specialized literature regarding the role of the forms of active tourism on the physical training of the students aged 13-14 years.

2. Identifying the priority forms of active tourism that favor the physical development of 13-14 year old students.

3. Theoretical and experimental argumentation of the physical training of 1314 year old students, as a result of practicing the forms of active tourism.

Research methods. In order to achieve the goal and the objectives, the following research methods were used: analysis of the specialized scientific-methodical literature; pedagogical observation; testing the level of physical training; pedagogical experiment; statistical-mathematical method of data processing; tabular method; graphic method.

Research organization. The research was conducted between September 10, 2018 September 10, 2019, with students aged 13-14 years, from two educational institutions in Chisinau (60 in number). The number of participants in various forms of active tourism (tourist marches, tourist contests, dynamic games of a tourist nature), organized by us, during the mentioned period who were subjected to tests were 30 students (experimental group), of which 15 girls and 15 boys, representing a ratio of $50 \%$ to $50 \%$.
Research results. In the domestic and international tourist activity, a wide range of active tourist forms is practiced, determined by the ways of satisfying the need of tourism, by the conditions of achieving the supply-demand balance, by the particularities of organizing the trip. In many places there are opportunities for practicing special forms of active tourism based on interesting or unusual local attractions, but also on the need for proper physical training.

According to the authors MachadoChaviano E.L., Aro Y. H. (2008), Каталимова А.Н., Бузни А.Н. (2007), Кугушева А. Н. (2012), the forms of active tourism are divided into several categories, which are distinguished by the mode of practice, area of development, degree of difficulty that requires appropriate physical training, etc., these being of nature (land, nautical and air) [3, 6, 8]. Proceeding from the fact that the most practiced are the forms of active tourism at the international level are the terrestrial ones, from the geographical particularities of the Republic of Moldova and in the context of the necessary equipment for the development of various forms of active tourism, active land-type tourism, namely: walking tours, tourist competitions in tourism and dynamic games with a tourist character (Figure 1).

The pedestrian-type tourist marches also included the involvement of 13-14 year old students in practicing dynamic games with a tourist character, but also the crossing of the technical stages, which according to Кодыш Э. (1990), enjoy an intense development in recent years, being quite difficult, requiring proper physical training [7]. The essence of the tourist marches was the long journey on the route that develops general endurance, but also the practice of stages in the technique of walking tourism that develops physical qualities such as strength, speed, skill, mobility, but also dynamic games with tourism that develops: speed, skill, etc. 


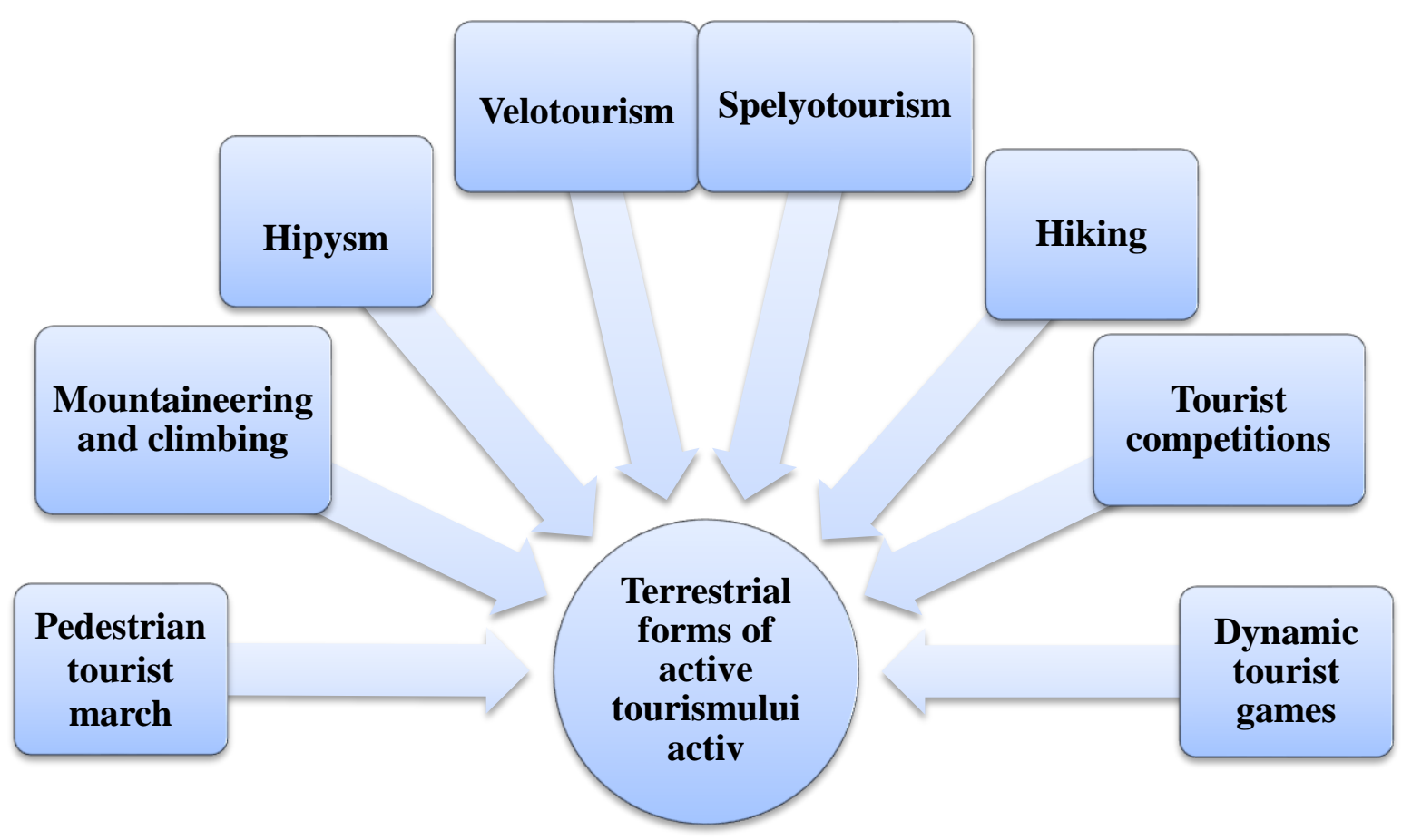

Fig. 1. Terrestrial forms of active tourism (those highlighted being used in the pedagogical experiment)

The technical stages organized within the pedagogical experiment with the sample subject to research included: overcoming natural obstacles, performing technical procedures, using tourist equipment and performing technical-tactical tasks (Figure 2). The competition route, which included the technical stages listed, was divided into stages, and a certain control time was determined for their completion.

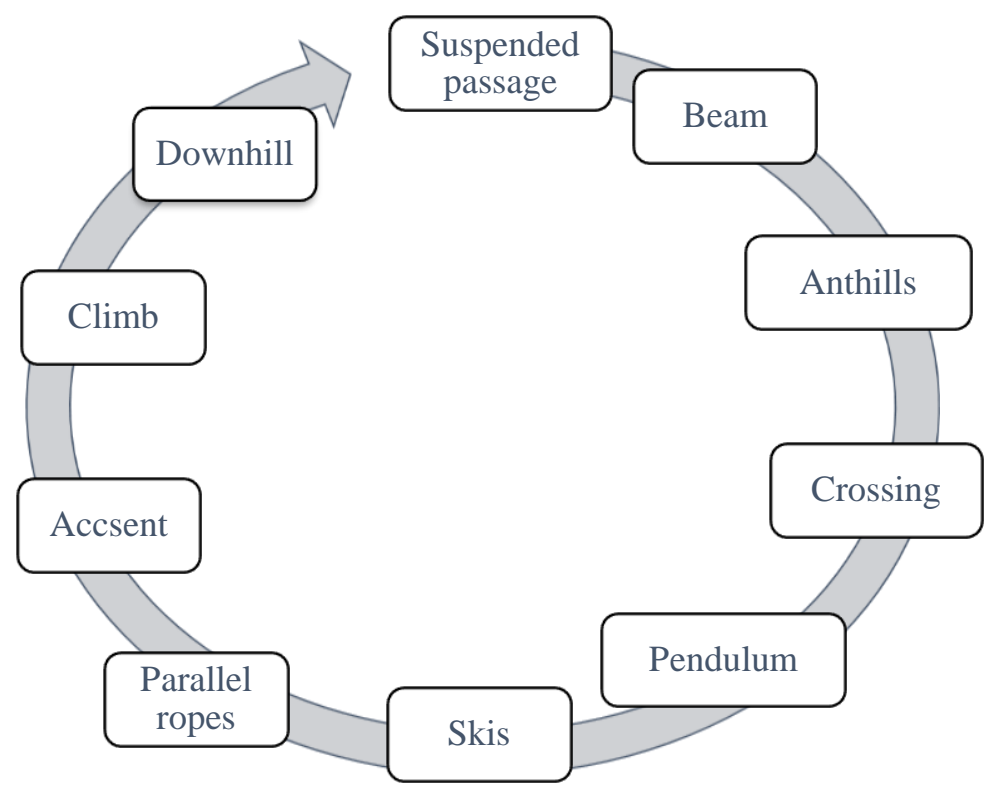

Fig. 2. The stages of the tourism technique organized within the pedestrian tourist march during the pedagogical experiment 
Within the tourist activities, as in other activities, the accomplishment of the tasks is impossible without the physical training, which is a component of the preparation and development of the activities, being indispensable and necessary in the functioning of the organism.

Through the measurement, and testing under standard conditions, of the sample established by us, the aim was to highlight the evolution of the parameters of general physical training, being an essential criterion in practicing the forms of active tourism.

In order to assess the level of physical training, various methodologies are used, most of them representing the measurement of some indicators.

Physical fitness tests are reflected in the physical education curriculum for primary and secondary schools Grimalschi T., Boian I, (2011), and the variety of products that assess skills include all compartments of the physical education curriculum at middle and high school level, which covers the following areas (according to the Learning Efficiency Standards):

1. The motor activity of the student.

2. Development of basic human motor qualities: skill (coordination), speed, suppleness (mobility), endurance, strength.

3. Diagnosis of the level of physical and functional training of the student.

4. Applicable physical exercises.

5. Basic motor skills: running, jumping, throwing (athletics); basic gymnastics; rhythmic, aerobic, dance; technical-tactical actions in attack and defense in sports games, etc.

According to the research conducted by Bucun N., Pogolşa L. Chicu V. (2014) and Grimalschi T., Boian I. (2011), the evaluation of the results of high school students is performed based on the results obtained by testing physical training and should record the following indices (eg 60m running - a result of 9.04 (sec) for girls and 8.5 (sec) for boys; $1000 \mathrm{~m}$ girls running - a result of $258(\mathrm{sec})$ and
$2000 \mathrm{~m}$ boys - 540 ( $\mathrm{sec})$; - 22, tractions - 8-15 depending on body mass) $[1,2]$.

To perform the experiment, the initial level of physical training of 13-14 year old students for both girls and boys was established (Table 1). The measurement and testing, under standard conditions, of the sample established by us, took place with the help of four tests, which highlighted the evolution of the general physical parameters. Thus, the following tests were used: speed running $60 \mathrm{~m}$, endurance running $1000 \mathrm{~m}$ (girls) and $2000 \mathrm{~m}$ (boys), push-ups on the gym bench (girls), traction at the fixed bar (boys). The tests were selected taking into account the motor qualities that are developed during the tourist marches, the technical stages of the pedestrian tourism technique, but also the dynamic tourist games.

The data obtained at the initial stage of the pedagogical experiment (Table 1) show that the value of the averages obtained by students is low for both girls and boys, compared to the evaluation criteria of students in the discipline of physical education in middle and high school, fact reflected by the short time and the small number of repetitions in the PFG samples.

From the analysis of the data obtained by applying the initial pre-experimental tests on the level of physical training of students, we considered that the dependent variables were studied in the initial, pre-experimental testing, by recording the situation on general physical training, in the context of Таймазов Ю., Федототова Н. (2014) mentions that in order to practice the forms of active tourism, a physical training is needed to ensure:

- general physical training;

- special physical training depending on the mode of movement and bypassing natural and artificial obstacles;

- hardening of the body - resistance to disease when the body is subjected to overheating, low temperatures, high humidity and dry air, lack of oxygen, etc. [10. p. 240]. 
Table 1. Initial level of general physical training of students aged 13-14 (girls $n=30$; boys $n=30$ )

\begin{tabular}{|c|c|c|c|}
\hline \multirow{2}{*}{$\begin{array}{l}\text { No. } \\
\text { crt. }\end{array}$} & \multirow[b]{2}{*}{ Parametres } & Girls & Boys \\
\hline & & $\bar{X} \pm \mathbf{m}$ & $\bar{X} \pm \mathbf{m}$ \\
\hline 1 & Running speed 60 m (sec) & $10,53 \pm 0,12$ & $9,58 \pm 0,10$ \\
\hline 2 & Endurance running1000 m (sec) & $320,54 \pm 3,62$ & - \\
\hline 3 & Endurance running $2000 \mathrm{~m}$ (sec) & - & $585,59 \pm 6,80$ \\
\hline 4 & $\begin{array}{c}\text { Push-ups on the gym bench (no. of } \\
\text { repetitions) }\end{array}$ & $16,10 \pm 0,63$ & - \\
\hline 5 & Fixed bar traction (no. of repetitions) & - & $8,52 \pm 0,56$ \\
\hline
\end{tabular}

After practicing the forms of active tourism with 13-14 year old students from the experimental group, the general physical training tests performed in the pedagogical experiment and comparing the recorded results show that the level of effort capacity and parameters recorded as a result of practicing forms of active tourism by students, are in progressive dynamics, the results obtained by the experimental group being superior to the control group in all categories of tests.

This aspect appears as a result of the application of terrestrial forms of active tourism, based mainly on technical stages of tourism.

The comparative analysis of the arithmetic means of the two groups at the initial and final stage of the experiment at the physical condition evaluation indices demonstrates the following data presented in Figures 3-5:

The indices of the initial $60 \mathrm{~m}$ running test for girls are 10.53 (experimental group) and 10.52 (control group). The final test represents a progress of 0.42 (average of 10.11) in the experimental group and 0.12 (average of 10.40) in the control group.

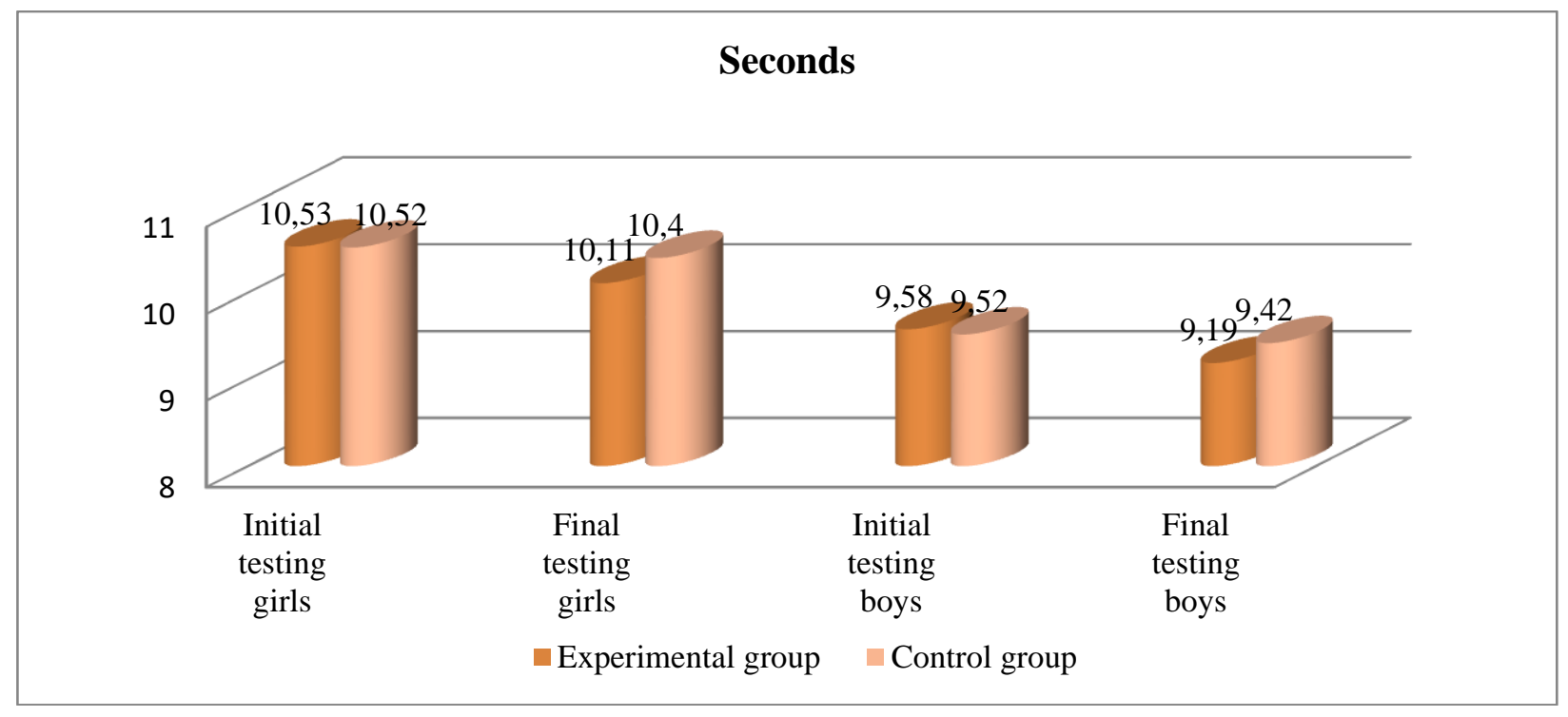

Fig. 3. Running test results $60 \mathrm{~m}$ (sec.) (Arithmetic mean) (girls $n=15$; boys $=15$ ) 
For boys, the initial test indices are 9.58 in the experimental group and 9.52 in the control group. The final test represents a progress of
0.39 (average of 9.19) in the experimental group and 0.1 (average of 9.42) in the control group.

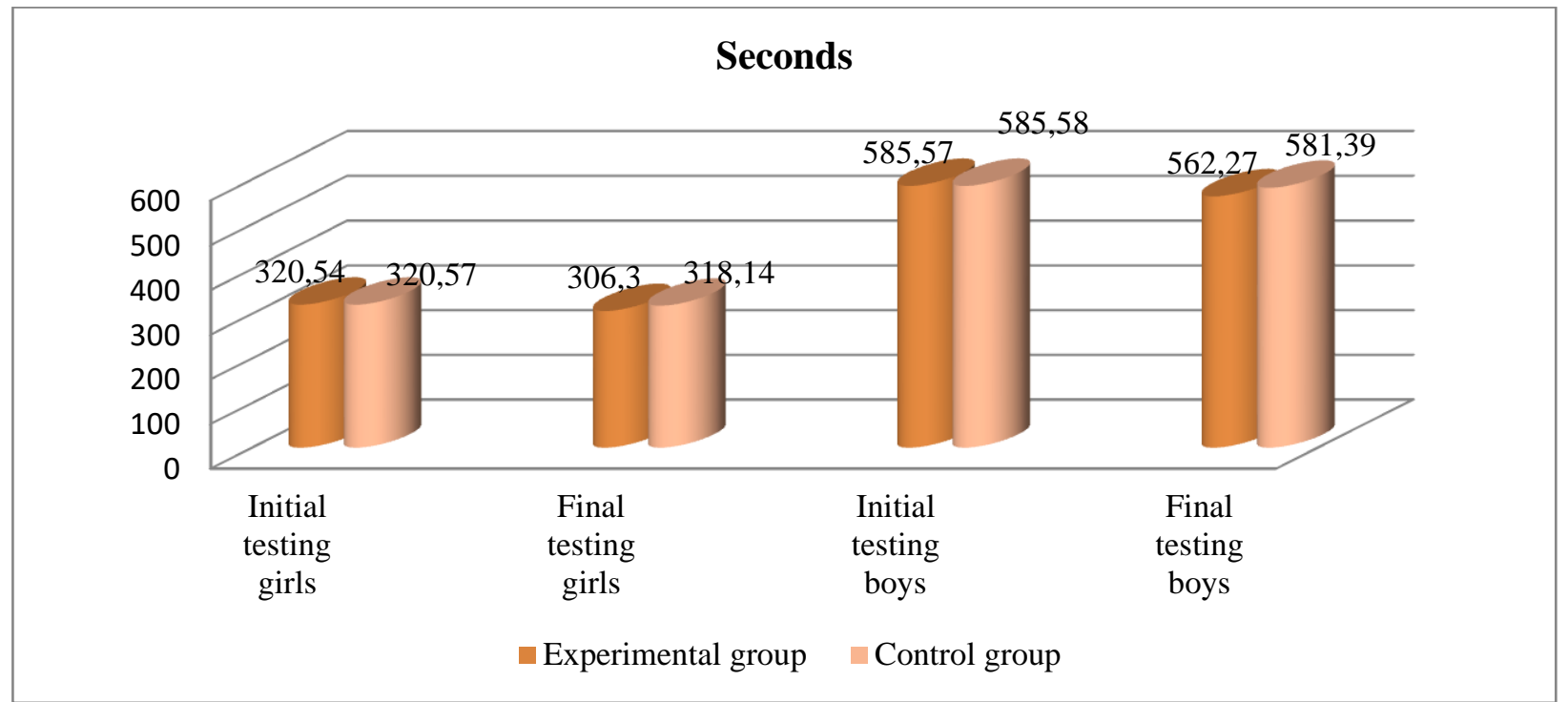

Fig. 4. Graphical representation of the results in the running of $1000 \mathrm{~m}$ (girls) and $2000 \mathrm{~m}$ (boys) (sec) (arithmetic mean) (girls $n=15$; boys $=15$ )

According to the values of the arithmetic means at the $1000 \mathrm{~m}$ endurance run (girls), there is a progress of $14.24 \mathrm{sec}$ (320.54 initial and 306.3 final) the experimental group and $2.43 \mathrm{sec}$ (320.57 initial and 318.14 final ) control group.
The boys recorded the following arithmetic values in the $\mathbf{2 0 0 0} \mathbf{m}$ endurance run: a progress of $23.3 \mathrm{sec}$ (585.57 initial and 562.27 final) experimental group and $4.19 \mathrm{sec}$ (585.58 initial and 581.39 final) group control.

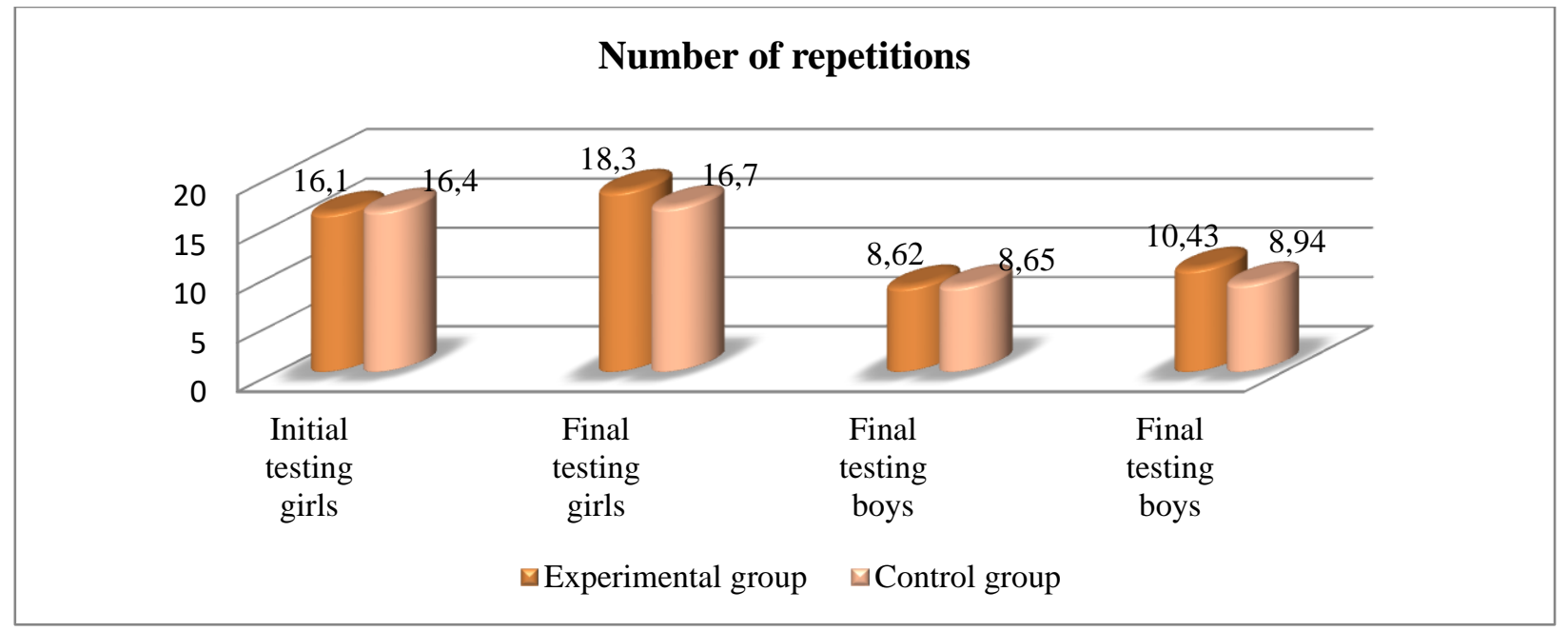

Fig. 5. Graphical representation of the results in the push-ups (girls) and traction (boys) test (arithmetic mean) (girls $n=15$; boys $=15$ ) 
The values of the arithmetic means at the push-up test (girls) register a progress of 2.2 repetitions (16.1 initial and 18.3 final) of the experimental group and 0.3 repetitions $(16.40$ initial and 16.70 final) of the control group.

The boys recorded the following average values at the traction test: a progress of 1.81 repetitions (8.62 initial and 10.43 final) in the experimental group and 0.29 repetitions (8.65 initial and 8.94 final) in the control group.

Analyzing the results of the average values at the physical training tests we can see that in the final tests the results of the subjects from both groups are better than those recorded in the initial tests. The progress made by 13-14 year old students in the experimental group is much more significant than that of the control group in all tests. We can appreciate that the terrestrial forms of active tourism realized within the pedagogical experiment had an essential role on the physical training of the students from the experimental group. Thus, from the research, whose results (arithmetic means) were presented above, regarding the level of general physical training, it was observed that the practice of terrestrial forms of active tourism increase the level of physical training of students.

This statement is based on the improvement of the physical training results of 13-14 year old students by the overall increase of the results obtained at the final test in the experimental group compared to the control group and compared to those recorded at the initial test, as seen in Tables 3 and 4.

The better physical training of the students from the experimental group at the final stage was determined by practicing the forms of active tourism, included in the program of tourist activities that were implemented to the experimental group, only after analyzing the results of initial tests that demonstrated the initial training research subjects.

Thus, the subjects investigated in the experiment were initially subjected to primary testing (data were assessed in the sec. In physical fitness tests in the $60 \mathrm{~m}$ girls and boys; $1000 \mathrm{~m}$ girls and $2000 \mathrm{~m}$ boys; push-ups - girls and tractions - boys), up to when implementing forms of active tourism. During the investigation, the control group did not use the competition stages for the proposed pedestrian tourism technique, thus continuing the activities in the usual regime, and the one subjected to the research according to the proposed technique, were subjected to final testing.

Analyzing the centralized data in Tables 3 and 4 , it can be seen that the values recorded in the initial and final tests in the case of the control group, which did not practice land forms of active tourism, confirm the existence of a similar level of training between the two groups included in the pedagogical experiment. The differences between them are obvious when comparing the results recorded at the initial and final testing in the experimental group, which used the terrestrial forms of active tourism, both for girls $(\mathrm{t}=4.14, \mathrm{P}$ $<0.001 ; \mathrm{t}=4.61, \mathrm{P}<0.001 ; \mathrm{t}=3.19, \mathrm{P}<0.01)$, as well as for boys $(\mathrm{t}=4.83, \mathrm{P}<0.001 ; \mathrm{t}=4.91$, $\mathrm{P}<0.001 ; \mathrm{t}=3.75, \mathrm{P}<0.01)$.

As shown by the comparative analysis of the results recorded by girls in the initial and final tests of the experimental and control groups, the average value of the initial level of training in the experimental and control group is insignificant $(\mathrm{P}>0.05)$ in all 3 tests.

At the final test, the mean level of the subjects in the experimental group compared to those in the control group in almost all 3 tests performed showed significant differences ( $\mathrm{P}<0.001$ ), except for the test (push-ups from support on the gym bench) in which the increase was insignificant $(\mathrm{P}>0.05)$. However, the experimental group recorded significant differences between the initial and final testing $(\mathrm{P}<0.01 ; \mathrm{P}<0.001)$. 
Table 3. Results of the initial and final tests of the experimental and control groups at the 3 tests (girls $n=15$ )

\begin{tabular}{|c|c|c|c|c|c|c|}
\hline \multirow{2}{*}{$\begin{array}{l}\dot{\dot{U}} \\
\dot{0}\end{array}$} & \multirow{2}{*}{ Tests } & \multirow{2}{*}{ 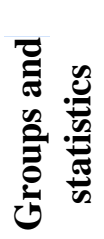 } & \multirow{2}{*}{$\begin{array}{c}\text { Initial } \\
\text { indices } \\
\bar{X}_{ \pm} \mathbf{m}\end{array}$} & \multirow{2}{*}{$\begin{array}{c}\text { Final } \\
\text { indices } \\
\bar{X}_{ \pm} \mathbf{m}\end{array}$} & \multicolumn{2}{|c|}{$\begin{array}{c}\text { Statistical } \\
\text { significance }\end{array}$} \\
\hline & & & & & $\mathbf{t}$ & p \\
\hline \multirow{4}{*}{1} & \multirow{4}{*}{$\begin{array}{c}\text { Running speed } 60 \mathrm{~m} \\
\text { (sec) }\end{array}$} & $\mathbf{E}$ & $10,53 \pm 0,12$ & $10,13 \pm 0,09$ & $\overline{4,14}$ & $<0,001$ \\
\hline & & $\mathbf{M}$ & $10,74 \pm 0,13$ & $10,60 \pm 0,12$ & 1,20 & $>0,05$ \\
\hline & & $\mathbf{t}$ & 0,95 & 2,98 & - & - \\
\hline & & $\mathbf{p}$ & $>0,05$ & $<0,01$ & - & - \\
\hline \multirow{4}{*}{2} & \multirow{4}{*}{$\begin{array}{c}\text { Running speed } 1000 \mathrm{~m} \\
\text { (sec) }\end{array}$} & $\overline{\mathbf{E}}$ & $320,84 \pm 3,62$ & $308,47 \pm 2,47$ & $\overline{4,61}$ & $<0,001$ \\
\hline & & $\mathbf{M}$ & $321,19 \pm 3,64$ & $318,51 \pm 2,62$ & 0,87 & $>0,05$ \\
\hline & & $\mathbf{t}$ & 0,28 & 2,78 & - & - \\
\hline & & $\mathbf{p}$ & $>0,05$ & $<0,01$ & - & - \\
\hline \multirow{4}{*}{3} & \multirow{4}{*}{$\begin{array}{c}\text { Pushups } \\
\text { from support on the } \\
\text { gym bench (no. of } \\
\text { repetitions) }\end{array}$} & $\overline{\mathbf{E}}$ & $16,10 \pm 0,63$ & $18,20 \pm 0,52$ & 3,19 & $\begin{array}{l}<0,01 \\
\end{array}$ \\
\hline & & $\mathbf{M}$ & $15,80 \pm 0,67$ & $16,53 \pm 0,60$ & 1,22 & $>0,05$ \\
\hline & & $\mathbf{t}$ & 0,74 & 2,10 & - & - \\
\hline & & $\mathbf{p}$ & $>0,05$ & $<0,05$ & - & - \\
\hline
\end{tabular}

According to the analysis presented in Table 4, the results recorded by the boys in the

experimental and control groups at the initial test are insignificant $(\mathrm{P}>0.05)$ in all 3 tests.

Table 4. Results of the initial and final testing of the experimental and control groups (boys n = 15)

\begin{tabular}{|c|c|c|c|c|c|c|}
\hline \multirow{2}{*}{$\begin{array}{l}\dot{0} \\
\dot{0} \\
\dot{Z}\end{array}$} & \multirow{2}{*}{ Tests } & \multirow{2}{*}{ 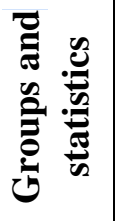 } & \multirow{2}{*}{$\begin{array}{c}\text { Initial } \\
\text { indices } \\
\bar{X}_{ \pm} \mathbf{m}\end{array}$} & \multirow{2}{*}{$\begin{array}{c}\text { Final } \\
\text { indices } \\
\bar{X}_{ \pm} \mathbf{m}\end{array}$} & \multicolumn{2}{|c|}{$\begin{array}{l}\text { Statistical } \\
\text { significance }\end{array}$} \\
\hline & & & & & $\mathbf{t}$ & $\mathbf{p}$ \\
\hline \multirow[t]{4}{*}{1} & \multirow{4}{*}{$\begin{array}{l}\text { Running speed } 60 \mathrm{~m} \\
\text { (sec) }\end{array}$} & $\overline{\mathbf{E}}$ & $9,58 \pm 0,10$ & $9,21 \pm 0,09$ & 4,83 & $<<0,001$ \\
\hline & & $\mathbf{M}$ & $9,63 \pm 0,09$ & $9,60 \pm 0,08$ & 0,44 & $>0,05$ \\
\hline & & $\mathbf{t}$ & 0,03 & 2,88 & - & - \\
\hline & & $\mathbf{p}$ & $>0,05$ & $<0,01$ & - & - \\
\hline \multirow{4}{*}{2} & \multirow{4}{*}{$\begin{array}{c}\text { Running speed } 2000 \mathrm{~m} \\
\text { (sec) }\end{array}$} & $\mathbf{E}$ & $585,61 \pm 6,80$ & $\overline{564,50 \pm 5,14}$ & 4,91 & $<0,001$ \\
\hline & & $\mathbf{M}$ & $591,78 \pm 7,00$ & $587,64 \pm 6,89$ & 0,78 & $>0,05$ \\
\hline & & $\mathbf{t}$ & 0,63 & 2,89 & - & - \\
\hline & & p & $>0,05$ & $<0,01$ & - & - \\
\hline \multirow{4}{*}{3} & \multirow{4}{*}{$\begin{array}{c}\text { Traction at the fixed } \\
\text { bar } \\
\text { (no. of repetitions) }\end{array}$} & $\overline{\mathbf{E}}$ & $8,72 \pm 0,56$ & $10,59 \pm 0,42$ & 3,75 & $<0,01$ \\
\hline & & $\mathbf{M}$ & $8,40 \pm 0,62$ & $9,00 \pm 0,51$ & 1,35 & $>0,05$ \\
\hline & & $\mathbf{t}$ & 0,10 & 2,36 & - & - \\
\hline & & $\mathbf{p}$ & $>0,05$ & $<0,05$ & - & - \\
\hline
\end{tabular}


In the final test, subjects in the experimental group showed statistically significant differences from those in the control group in almost all 3 tests performed $(\mathrm{P}<0.01)$, except for fixed bar traction, in which the increase was insignificant $(\mathrm{P}<0$, 05). However, the differences between the initial and final test results in the experimental group were significant $(\mathrm{P}<0.01 ; \mathrm{P}<0.001)$.

Conclusions. Active tourism consists of several forms (land, air, and nautical), but the most popular today according to data presented by several international organizations in the field of tourism, remain the land, which are more accessible from various points of view, of travel, finances, way of practice, etc.

The tasks of active tourism can be formulated as follows: multilateral personality development, physical training, mastering technical procedures, tourist exercises and exercises in other sports events, learning tourism-sports tactics, training skills and abilities on education and development of intellectual, moral, social, volitional qualities.
As a result of the implementation of active tourism forms, it can be stated that 13-14 year old students included in the pedagogical experiment have progressed in terms of general physical training, showing an increase in indicators in the four tests. The comparative analysis of the test results of the physical training level shows that the differences between them appear obviously in the case of comparing the initial and final indices of the subjects from the experimental group, at the speed running test for both girls $(\mathrm{t}=4.14, \mathrm{P}$ $<0.001)$, as well as for boys $(\mathrm{t}=4.83, \mathrm{P}$ $<0.001)$, endurance running test for girls $(t=$ 4.61, $\mathrm{P}<0.001)$ and boys $(\mathrm{t}=4.91, \mathrm{P}<0.001)$. In the push-up and traction test, respectively, the differences are also significant for both girls and boys $(\mathrm{P}<0.01)$. Based on the data obtained we can say that the forms of land tourism selected and implemented (tourist walks, hikes, tourist competitions in tourism and dynamic games with tourism), which require participants certain motor skills, had a major impact on general physical training of 13-14 year old students from the experimental group.

\section{References:}

1. Bucun N., Pogolşa L., Chicu V. (2014). Referențialul de evaluare a competențelor specifice formate elevilor. Chişinău. 546 p.

2. Grimalschi T., Boian I. (2011). Ghid de implementare a curriculumului modernizat pentru treptele primară și gimnazială. Chișinău.

3. Machado-Chaviano E. L., Aro Y. H. (2008). Del turismo contemplativoal turismo activo. On: Revista el periplo sustentable. Universitat Autrnoma del Estado Mexico. Publication Semestrial. Numero 15. Julio/Deciembre, p.119.

4. Биржаков А. М. (2008). Введение в туризм. Москва, с. 6-13.

5. Вереснева М.А., Новикова Д.С., Фарбей Г.Г. (2004). Исследование рынка потребителей крымского турпродукта. В: Культура народов Причерноморья, № 50. Т.3, с. 7-57.

6. Каталимова А.Н., Бузни А.Н. (2007). Исследование потребностей в активном туризме. В: Культура народов Причерноморья, №121, с. 40-45.

7. Кодыш Э. (1990). Соревнования туристов. Пешеходный туризм. Москва: Физкультура и спорт. $126 \mathrm{c.}$

8. Кугушева А. (2012). Теоретические аспекты активного туризма. В: Сервис в России и за рубежом, № 8, Т. 35. Москва, с. 43-52.

9. Мартыновская А. (2016). Активный туризм: специфика продукта. В: Научнометодический электронный журнал «Концепт», Т. 45, с. 86-89.

10. Таймазов Ю., Федототова Н. (2014). Теория и методика спортивного туризма. Москва: Советский спорт. 240 с. 